\title{
Upaya Peningkatan Kemampuan Analisis Data Penelitian Menggunakan Software Statistik Bagi Guru-Guru Matematika SMA Kabupaten Pesisir Selatan
}

\author{
Syafriandi ${ }^{1)}$, Nonong Amalita ${ }^{1)}$, Yenni Kurniawati ${ }^{1)}$ \\ ${ }^{1)}$ Jurusan Matematika, FMIPA Universitas Negeri Padang \\ syafriandi_math@fmipa.unp.ac.id
}

\begin{abstract}
Scientific publication is one of teacher's duty to increase their rank, form III/b to III/c. Base on interview with Senior High School teachers at Pesisir Selatan regency, we know that difficult for them to produce scientific publication caused by their ability on choosing data analysis technique which relevant to their case, teachers cannot use the statistical software because its not familiar for them, and they have low quality in interpreting data analysis result. To solve the problems, we offer a workshop of data analysis on scientific writing using statistical software. The target audiences of this workshop is a Group of Teachers on Mathematics Major (MGMP) in Pesisir Selatan. In this workshop, participants are given the basic concept and how to write a scientific writing, basic concept of statistics, and introduction to statistical software i.e. Minitab and SPSS. Beside that, with practical work, the participants learn how to use statistical software and interpretate the data analysis result. Result of the workshops are (1) increasing the ability of participants skills on analysis the data using statistical software and interpretate it.
\end{abstract}

Keywords : Scientific Publication, Statistical Analysis, Statistical Software

(i) his is an open access article distributed under the Creative Commons 4.0 Attribution License, which permits unrestricted use, distribution, and reproduction in any medium, provided the original work is properly cited $\odot 2018$ by author and Universitas Negeri Padang.

\section{PENDAHULUAN}

Guru sebagai tenaga profesional mem punyai fungsi, peran, dan kedudukan yang sangat penting dalam mencapai visi pendidikan. Salah satu visi pendidikan yaitu menciptakan insan Indonesia cerdas dan kompetitif. Untuk itu, profesi guru harus dikembangkan sebagai profesi yang bermartabat sebagaimana diamanatkan dalam Undang-Undang Nomor 14 Tahun 2005 tentang Guru dan Dosen.

Untuk mewujudkan guru sebagai tenaga profesional, diperlukan suatu sistem pembinaan dan pengembangan terhadap profesi guru secara terprogram dan berkelanjutan. Salah satu prog ram yang dirancang untuk mewujudkan ter bentuknya guru yang profesional adalah Pengem bangan Keprofesian Berkelanjutan (PKB). Pengembangan keprofesian berkelanjutan meru pakan pengembangan kompetensi guru yang dilaksanakan sesuai dengan kebutuhan, bertahap, dan berkelanjutan untuk meningkatkan pro fesionalitas guru.

Peraturan Menteri Negara Pendayagunaan Aparatur Negara dan reformasi Birokrasi (Permenegpan dan RB) Nomor 16 Tahun 2009, menegaskan bahwa untuk kenaikan jabatan/ pangkat guru, mulai dari golongan III/b ke III/c diwajibkan menghasilkan publikasi ilmiah. Pada peraturan sebelumnya guru diwajibkan meng hasilkan publikasi ilmiah hanya untuk guru yang akan naik pangkat mulai dari golongan IV/a ke IV/b. Keluarnya Permenegpan dan RB Nomor 16 Tahun 2009 tersebut berdampak terhadap lambatnya para guru untuk naik pangkat, karena tidak memiliki publikasi ilmiah.

Menurut Mahsunah, dkk. (2013), publikasi ilmiah adalah karya tulis ilmiah yang telah dipublikasikan kepada masyarakat sebagai ben tuk kontribusi guru terhadap peningkatan kualitas proses pembelajaran di sekolah. Secara umum publikasi ilmiah sebagai bentuk kontri busi guru dalam pengembangan dunia pendi dikan. Publikasi ilmiah mencakup tiga kelom pok, yaitu: presentasi pada forum ilmiah, pub likasi ilmiah berupa hasil penelitian atau gagasan ilmu bidang pendidikan formal, serta publikasi buku teks pelajaran, buku pengayaan, dan/atau pedoman guru.

Kenyataan di lapangan menunjukkan bah wa, masih banyak guru yang belum produktif 
dalam menghasilkan publikasi ilmiah dan karya inovatif. Ini terlihat dari banyaknya guru yang terhenti kenaikan pangkatnya yang disebabkan oleh tidak terpenuhinya syarat publikasi ilmiah dan karya inovatif. Hal ini disebabkan karena kurangnya kemampuan dan keterampilan guru dalam menulis karya ilmiah.

Berdasarkan hasil wawancara yang dila kukan terhadap beberapa orang guru Matematika SMA di Kabupaten Pesisir Selatan, diperoleh informasi bahwa kendala yang dihadapi dalam menghasilkan publikasi ilmiah dan karya ino vatif, khususnya karya ilmiah berupa hasil penelitian adalah 1) motivasi dan kemampuan menulis yang rendah; 2) tidak memiliki cukup waktu, dikarenakan beban mengajar yang padat dan tuntutan administrasi pelaksanaan tugas guru yang cukup banyak; 3) kurangnya pemahaman tentang teknik penulisan; dan (4) kesulitan menyusun instrumen penelitian. Selain itu, di bidang analisis data juga ditemukan kendala bahwa: 1) kurangnya kemampuan guru dalam memilih teknik analisis data yang sesuai; 2) rendahnya kemampuan guru memanfaatkan Software statistika dalam melakukan analisis data; dan 3) rendahnya kemampuan guru dalam memaknai dan menginterpretasikan hasil analisis.

Pengetahuan tentang statistika perlu dimiliki agar proses analisis data dapat dilakukan dengan baik. Menurut Bluman (2012), Statistika adalah ilmu yang mempelajari tentang cara-cara mengumpulkan, mengolah, dan menganalisis data, serta menginterpretasikan hasil analisis yang diperoleh. Jadi, tidak ada statistika kalau tidak ada data. Untuk itu pengetahuan awal yang perlu dimiliki adalah pengetahuan tentang data dan jenisnya. Data yang merupakan bentuk jamak dari datum. Data merupakan kumpulan informasi yang diperoleh dari hasil pengamatan atau pengukuran yang dapat berupa angka, lambang, atau sifat. Berdasarkan sifatnya data dapat dikelompokkan menjadi dua bagian yaitu: 1) data kualitatif (non-metric), dan 2) data kuantitatif (metric) (Hasan, 2004). Lebih lanjut, Glenberg (2008) membagi data kualitatif men jadi data nominal dan data ordinal, sedangkan data kuantitatif dikelompokkan menjadi data interval dan data rasio.

Data yang diperoleh dianalisis meng gunakan dua jenis Statistika, yaitu Statistika Deskriptif dan Statistika Inferensial. Walpole (1993) mendefinisikan bahwa Statistika Deskrip tif adalah Statistika yang digunakan untuk meng analisis data dengan cara mendeskripsikan atau menggambarkan data sebagaimana adanya tanpa bermaksud melakukan generalisasi.

Pendeskripsian data dapat menggunakan tabel dan grafik. Beberapa tabel yang dapat digunakan adalah tabel frekuensi, tabel distribusi frekuensi, tabel distribusi frekuensi kumulatif, dan tabel distribusi frekuensi relatif. Selanjutnya, penyajian data menggunakan grafik dapat berupa diagram batang, histogram, diagram lingkaran, polygon frekuensi, ogive, diagram batang-daun, dan diagram kotak garis (Bluman, 2012). Statistika deskriptif juga membahas tentang ukuran statistik bagi data, berupa ukuran pemusatan (rata-rata, median, modus), ukuran keragaman (jangkauan, simpangan antar kuartil, variansi, dan simpangan baku), serta ukuran letak berupa (kuartil, desil, dan persentil).

Holt \& Scariano (2009) menegaskan bahwa dalam mendeskripsikan data, perlu kehatihatian dalam memilih grafik dan ukuran statistik bagi data. Misalnya "ukuran pemusatan mana yang seharusnya digunakan untuk aplikasi tertentu?". Untuk data kuantitatif selayaknya menggunakan rata-rata, sedangkan untuk data kualitatif ukuran pemusatan yang sesuai adalah modus. Demikian juga untuk diagram batang digunakan untuk data kualitatif, dan histogram digunakan untuk data kuantitatif.

Statistika inferensial adalah statistika yang digunakan untuk menganalisis data sampel dan hasilnya diberlakukan untuk menyimpulkan populasi (dapat digenaralisasi). Bluman (2012) menjelaskan bahwa statistika inferensial menca kup generalisasi sampel terhadap populasi, melakukan pendugaan dan pengujian hipotesis, menentukan hubungan antar variabel, dan mem buat prediksi. Untuk memahami konsep statistika inferensial, disamping memahami prosedur peng ujian yang digunakan, juga diperlukan pema haman tentang interpretasi hasil yang diperoleh.

Terdapat dua jenis statistika inferensial, yaitu statistika parametrik dan statistika non parametrik. Statistika parametrik merupakan statistika yang taat asumsi, yaitu analisis yang didasarkan atas asumsi bahwa data memiliki sebaran tertentu dengan parameter yang belum diketahui. Fungsi statistika parametrik adalah untuk meramalkan parameter, atau melakukan uji parameter. Statistika parametrik kebanyakan digunakan untuk menganalisis data interval atau rasio.

Statistika Nonparametrik merupakan ana lisis yang tidak didasarkan atas asumsi distribusi 
pada data. Umumnya teknik ini dipakai untuk data dengan ukuran kecil sehingga tidak cukup kuat untuk mengasumsikan distribusi tertentu pada data. Statistika Nonparametrik kebanyakan digunakan untuk menganalisis data nominal atau ordinal.

Berbagai hasil penelitian mengungkapkan bahwa terdapat berbagai permasalahan dalam penggunaan statistika inferensial, terutama pada penggunaan pengujian hipotesis. Mendez (1991) dan Garfield \& Ahlgren (1988) mengungkapkan bahwa peneliti sering melihat bahwa pengujian hipotesis hanya sebagai seperangkat prosedur perhitungan. Tanpa prosedur tersebut pengujian hipotesis tidak memiliki banyak makna bagi mereka. Selanjutnya, hasil penelitian Castro, et al (2007), Thompson, Liu, \& Saldahna (2007), Haller \& Krauss (2002), dan Batanero (2000) mengungkapkan bahwa terdapat beberapa kesu litan dalam melakukan uji hipotesis, diantaranya kesulitan dalam mengidentifikasi hipotesis nol dan hipotesis alternatif, kesulitan dalam menaf sirkan tingkat signifikansi dan p-value, dan gagal untuk memahami peran distribusi sampling dalam pengujian hipotesis.

Berdasarkan uraian yang dikemukanan di atas, rumusan masalah yang dikemukakan adalah apakah pelatihan analisis data menggunakan software statistika dapat meningkatkan kemam puan guru matematika SMA Kabupaten Pesisir Selatan dalam melakukan analisis data untuk menghasilkan karya ilmiah. Untuk itu tujuan yang ingin dicapai adalah pelatihan analisis data menggunakan software statistika dapat mening katkan kemampuan guru Matematika SMA di Kabupaten Pesisir Selatan dalam menganalisis data, sehingga dapat menghasilkan karya ilmiah yang berkualitas.

\section{METODE PENELITIAN}

Metode yang digunakan untuk memecah kan masalah penelitian ini adalah metode des kriptif, yaitu menggambarkan secara sistematis dan mengiterpretasikan objek sebagaimana ada nya. Teknik pengumpulan data yang digunakan adalah teknik pretest-post test dan teknik observasi. Untuk melihat kemampuan awal res ponden terlebih dahulu dilakukan pretest dan untuk melihat peningkatan kemampuan respon den di akhir kegiatan dilakukan post-test. Selan jutnya untuk melihat keterampilan responden dalam melakukan analisis data dilakukan obser vasi. Data yang terkumpul dianalaisis menggu nakan analisis deskritif dan analisis inferensial.

\section{HASIL DAN PEMBAHASAN}

Pengetahuan awal responden diukur mela lui pemberian pre-test. Terdapat lima kelompok materi yang diujikan dalam pre-test, yaitu: (1) pengetahuan tentang pengembangan keprofesian berkelanjutan (PKB); (2) penelitian tindakan ke las (PTK) dan karya ilmiah (KI); (3) pengeta huan dasar statistika; (4) analisis statistika para metrik; dan (5) analisis statistika non parametrik. Deskripsi hasil pre-test terdapat pada Tabel 1.

Tabel 1. Deskripsi Hasil Pre-Test

\begin{tabular}{|l|c|c|r|r|c|}
\hline \multicolumn{1}{|c|}{ Materi } & \multicolumn{1}{c|}{ X } & S & Med & Min & Maks \\
\hline PKB & 65,56 & 23,95 & 66,67 & 33,33 & 100,00 \\
\hline PTK dan KI & 60,48 & 12,46 & 62,78 & 36,67 & 84,44 \\
\hline Dasar Statistika & 57,78 & 16,80 & 66,67 & 16,67 & 83,33 \\
\hline Stat. Parametrik & 52,00 & 13,24 & 50.00 & 30,00 & 80 \\
\hline Stat. Non Parametrik & 28,33 & 28,42 & 50,00 & 0,00 & 100,00 \\
\hline General & $\mathbf{5 6 , 8 3}$ & $\mathbf{9 , 2 8}$ & $\mathbf{5 8 . 7 5}$ & $\mathbf{4 2 , 5 0}$ & $\mathbf{7 2 , 5 0}$ \\
\hline
\end{tabular}

Tabel 1 memperlihatkan bahwa secara umum (general) rata-rata kemampuan awal guruguru matematika SMA di Kabupaten Pesi sir Selatan tentang analisis data statistik masih rendah, yakni 56,83 (skala 0 - 100) dengan simpangan baku 9,28. Hal ini menunjukkan bahwa kemampuan awal yang dimiliki guru-guru tentang penguasaan materi yang akan dilatihkan baru mencapai 56,83\% dengan kemampuan antar guru yang cukup beragam $(9,28)$. Nilai median menunjukkan bahwa $50 \%$ peserta memiliki kemampuan di bawah 58,75. Ini berarti bahwa separoh peserta memiliki pengetahuan tentang materi yang akan dilatihkan di bawah $58,75 \%$. Diantara lima topik pelatihan yang diujikan pemahaman tentang pengetahuan statistika, yakni: dasar-dasar statistika, analisis data para metrik, dan analisis data non parametrik memi liki nilai rata-rata yang rendah.

Memanfaatkan hasil pre-test tersebut, gu ru-guru sebagai peserta dibekali dengan konsepkonsep dasar materi, terutama tentang konsep statistika dasar, statistika parametrik, dan statis tika non parametrik. Pengetahuan yang telah diperoleh peserta diaplikasikan dengan berbagai jenis data dan dianalisis menggunakan software statistika yaitu Minitab dan SPSS. Di awal kegiatan praktikum terlihat bahwa para guru belum mampu menggunakan kedua software untuk menganalisis data, bahkan sebagian besar guru belum mengenal kedua software tersebut. Untuk itu kegiatan praktikum diawali dengan pengenalan kedua software tersebut. 
Data riil tentang kondisi siswa yang dimi liki masing-masing guru digunakan sebagai data untuk pelatihan ini. Data tersebut berupa data jenis kelamin siswa, data pekerjaan orang tua siswa, dan data nilai ulangan harian, nilai mid semester, dan data nilai akhir semester matema tika siswa. Data tersebut dianalisis menggunakan statistika deskriptif dan statistika inferensial. Statistika deskriptif berupa penyajian data meng gunakan tabel, grafik, dan ukuran statistik bagi data, sedangkan pada statistika inferensial berupa analisis parametrik dan analisis non parametrik.

Kegiatan pelatihan diawali dengan review teori tentang berbagai analisis data, berupa pem bahasan konsep analisis deskriptif dan analisis inferensial. Pada statistika deskriptif dibahas tentang pengertian data dan jenisnya, penyajian data menggunakan tabel dan grafik, dan penen tuan ukuran-ukuran statistik bagi data. Pada Statistika inferensial dibahas tentang konsep hipotesis, perbedaan statistika parameterik dan statistika non parameterik, dan berbagai analisis yang digunakan dalam statistika parametrik dan statistika non parametrik.

Guru-guru berlatih memanfaatkan soft ware statistika dalam membuat berbagai penya jian data menggunakan tabel dan grafik. Berba gai tabel yang dilatihkan adalah pembuatan tabel frekuensi, tabel distribusi frekuensi, dan tabel distribusi frekuensi kumulatif. Sedangkan berba gai grafik yang dilatihkan adalah diagram ba tang, diagram lingkaran, histogram, diagram da han-daun, dan diagram kotak garis. Peserta dila tih untuk terampil memilih jenis grafik yang se suai dengan jenis data yang dimiliki, dan kemam puan memberikan interpretasi terhadap tabel dan grafik yang dihasilkan. Hasil praktikum dari salah seorang guru terlihat pada Gambar 1 .

Gambar 1 memperlihatkan bahwa peserta telah mampu menyajikan data menggunakan ber bagai tabel, seperti tabel frekuensi, tabel frekuen si kumulatif, tabel distribusi frekuensi, dan tabel frekuensi relatif. Selanjutnya, para guru dilatih untuk menginterpretasikan data yang telah disa jikan pada tabel yang sudah diperoleh. Pada ba gian ini, para guru telah mampu memaknai data berdasarkan tabel yang telah dihasilkan, yakni pemaknaan tentang kelas interval yang dikaitkan dengan frekuensi, persentase, dan frekuensi kumulatif.

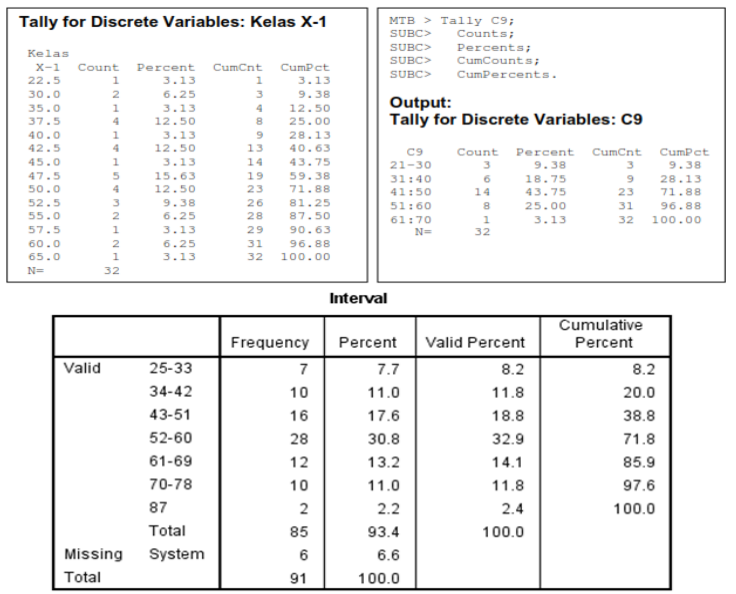

Gambar 1. Penyajian Data Menggunakan Tabel

Deskripsi data dilanjutkan dengan pem buatan berbagai jenis grafik, yaitu diagram ba tang, diagram lingkaran, histogram, diagram da han daun (stem and leaf), dan diagram kotak garis (box-plot). Pada kegiatan ini, para guru di minta untuk lebih hati-hati dalam memilih grafik yang sesuai dengan jenis data yang dianalisis. Misalkan untuk data kualitatif berskala nominal dan ordinal lebih tepat digunakan diagram ba tang, sedangkan untuk data kuantitaf berskala interval dan rasio digunakan histogram. Pela tihan memfokuskan pada keterampilan guru menggunakan software SPSS dan Minitab, serta kemampuan menginterpretasi grafik yang telah dihasilkan. Hasil salah seorang guru dapat dilihat pada Gambar 2.

Hasil pekerjaan guru seperti Gambar 2 dija dikan bahan diskusi oleh semua peserta untuk mendeskripsikan data menggunakan grafik yang telah dihasilkan. Tiga grafik yakni histogram, diagram dahan daun, dan diagram kotak garis dibandingkan. Pada bagian ini para guru mampu memanfaatkan ketiga grafik tersebut dalam mengidentifikasi distribusi dari data yang Diana lisis. Para guru telah mampu menyimpulkan bahwa distribusi dari data tersebut menyerupai distribusi normal. Pada histogram terlihat bahwa batang-batang yang membentuk histogram agak setangkup (simetrisi), hanya sebagian kecil data yang nilai datanya rendah agak menjulur ke kiri. Jika dibandingkan dengan diagram dahan daun dan diagram kotak garis, melalui diskusi para guru telah menyimpulkan ekor kiri dan ekor kanan dari garis pada diagram kotak garis hampir sama panjang, dan tidak terlihat adanya data pencilan. 


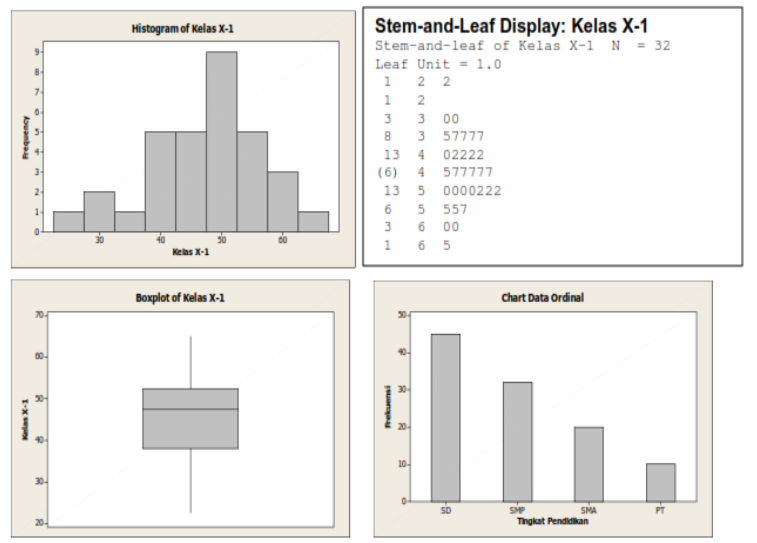

Gambar 2. Penyajian Data Menggunakan Grafik

Pendeskripsian data berikutnya yang dipraktikumkan adalah melakukan perhitungan ukuran statistik bagi data, berupa statistik lima serangkai (nilai minimum, nilai maksimum, kuar til 1, kuartil 2/median, dan kuartil 3), rataan, dan simpangangan baku. Pada bagian ini ditekankan bahwa untuk menghitung ukuran-ukuran tersebut sangatlah sederhana, karena software telah mem fasilitasi untuk melakukan perhitungan tersebut. Namun, yang paling penting adalah bagaimana memaknai hasil perhitungan ukuran statistik yang telah diperoleh. Hasil diskusi para guru menunjukkan bahwa mereka telah mampu mem bedakan manfaat ukuran pemusatan (rataan, me dian, dan modus) dengan ukuran keragaman (variansi dan simpangan baku). Diskusi juga menghasilkan bahwa untuk data kuantitatif, ukuran pemusatan yang paling tepat digunakan adalah rataan, karena perhitungan rataan meman faatkan seluruh data yang ada, sehingga hasil yang diperoleh mencerminkan kondisi dari keseluruhan data. Pada bagian ini para guru juga sudah mampu memilih ukuran pemusatan yang tepat sesuai dengan jenis data yang dimiliki. Misalkan untuk data kualitatif, rataan tidak dapat digunakan karena data kualitatif tidak dapat dilakukan operasi hitung. Untuk data kualitatif ukuran pemusatan yang cocok digunakan adalah modus. Hasil pemanfaatan software minitab dan SPSS oleh salah seorang guru dapat terlihat pada Gambar 3.

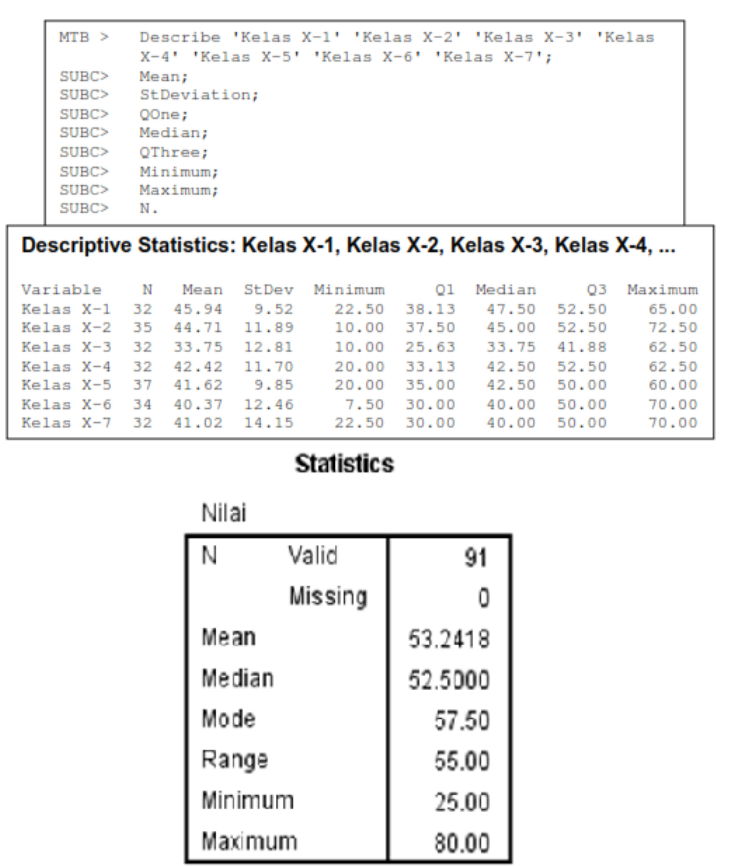

Gambar 3. Deskripsi Data Menggunakan Software Minitab dan SPSS.

Setelah kemampuan dan keterampilan guru-guru Matematika SMA Kabupaten Pesisir Selatan dalam menganalisis data secara deskrip tif meningkat, selanjutnya para guru dilatih mela kukan analisis data menggunakan statistika infe rensial. Beberapa analisis inferensial yang dila tihkan adalah adalah asumsi kenormalan, uji kehomogenan variansi, uji kesamaan rata-rata dua kelompok populasi, dan uji kesamaan ratarata lebih dari dua kelompok populasi. Hasil pelatihan menunjukkan bahwa, Para guru telah memiliki keterampilan dalam memilih uji yang sesuai dengan hipotesis yang dikemukakan. Mi salnya menguji kehomogenan variansi untuk be berapa kelompok populasi digunakan uji Bartlett, untuk menguji kesamaan rata-rata dua kelompok populasi digunakan uji $\mathrm{t}$ atau uji $\mathrm{z}$, dan untuk menguji kesamaan rata-rata lebih dari dua ke lompok populasi diggunakan uji Anova satu arah. Hasil salah satu pekerjaan guru seperti terlihat pada Gambar 4. 

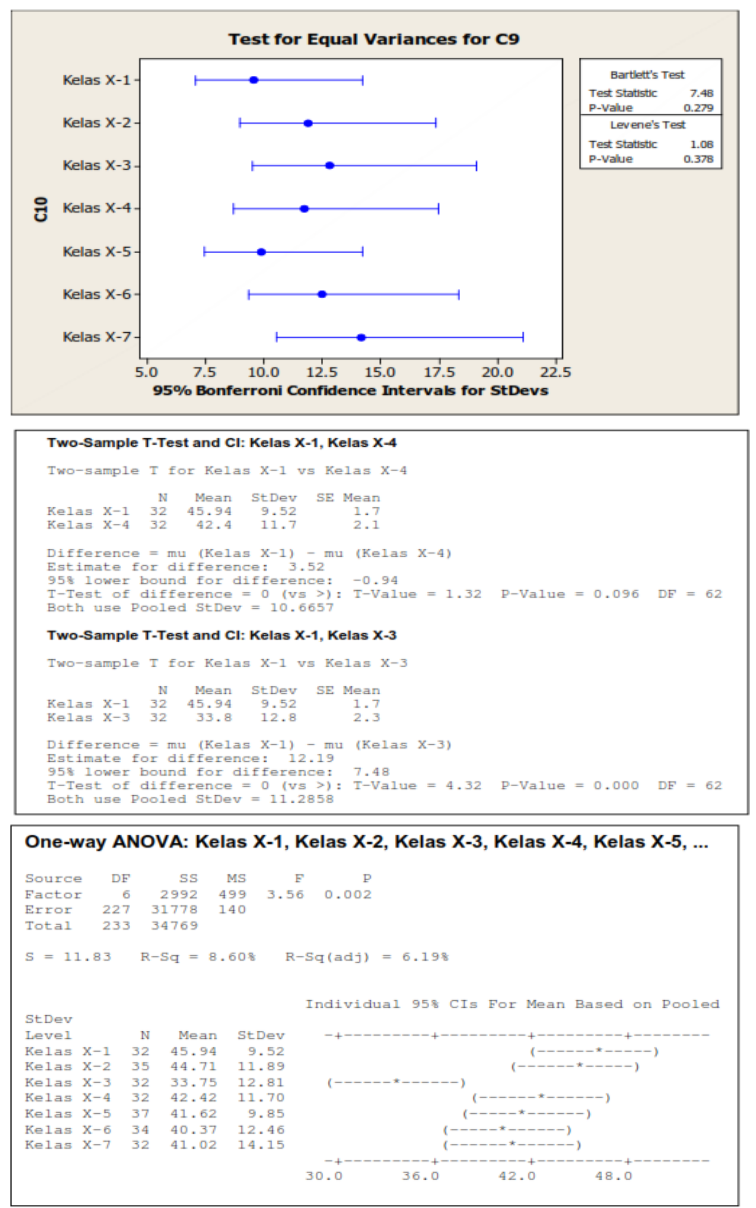

Gambar 4. Uji Kehomogenan Variansi, Uji Beda Dua Rataan Populasi, dan Uji Kesa maan Rataan Beberapa Kelompok Populasi

Melalui diskusi kelompok, para guru mengiterpretasikan hasil analisis berupa output dari software yang digunakan. Untuk menguji kehomogenan variansi, para guru telah mampu mamanfaatkan grafik selang kepercayaan untuk menarik kesimpulan. Para guru menyimpulkan bahwa karena semua grafik beririsan, maka dapat disimpulkan bahwa seluruh kelompok me miliki variansi yang sama (variansi homogen). Selain itu para guru juga telah mampu meman faatkan kriteria $p$-value. Uji Bartlet mengha silkan $\mathrm{p}$ value $=0,279>0,05$, maka dapat disim pulkan terima $\mathrm{H}_{\mathrm{o}}$, yakni seluruh kelompok popu lasi memiliki variansi yang homogen.

Demikian juga untuk uji kesamaan ratarata dua kelompok populasi, peserta telah mam pu memanfaatkan p-value dalam menarik kesim pulan. Hasil output menunjukkan bahwa, untuk uji rata-rata kelas X-1 dengan kelas X-4 dipero leh nilai $\mathrm{p}$-value $>0,05$ yang menunjukkan terima $\mathrm{H}_{0}$, artinya rata-rata nilai kelas $\mathrm{X}-1$ sama saja dengan rata-rata nilai kelas $\mathrm{X}-4$. Sedangkan untuk kelas X-1 dan X-3 diperoleh p-value < 0,05 yang menunjukan tolak $\mathrm{H}_{0}$, artinya rata-rata nilai kelas X-1 lebih baik dari rata-rata nilai kelas X-3 (uji satu arah).

Untuk uji kesamaan rata-rata lebih dari dua kelompok populasi menggunakan Anava, peserta telah mampu membaca hasil output, yaitu karena p-value $<0,05$, maka disimpulkan bahwa tolak $\mathrm{H}_{0}$, yang berarti minimal terdapat satu pasang rata-rata nilai diantara kelas tersebut yang berbeda. Selanjutnya dari grafik selang kepercayaan diperoleh bahwa rata-rata kelas X-3 berbeda dengan kelas $\mathrm{X}-1, \mathrm{X}-2$, dan X-4 karena tidak ada irisan.

Selanjutnya, untuk analisis non parametrik berbagai jenis analisis telah dipahami peserta, dan peserta memanfaatkan software untuk mela kukan analisis. Gambar 5 menunjukkan hasil uji Man-Whitney dan Uji tanda salah seorang peser ta. Peserta juga telah mampu menginterpreta sikan hasil output yang diperoleh, yakni, karena signifikan pada 0,000 , maka disimpulkan median kelas X-1 berbeda dengan median kelas X-3.
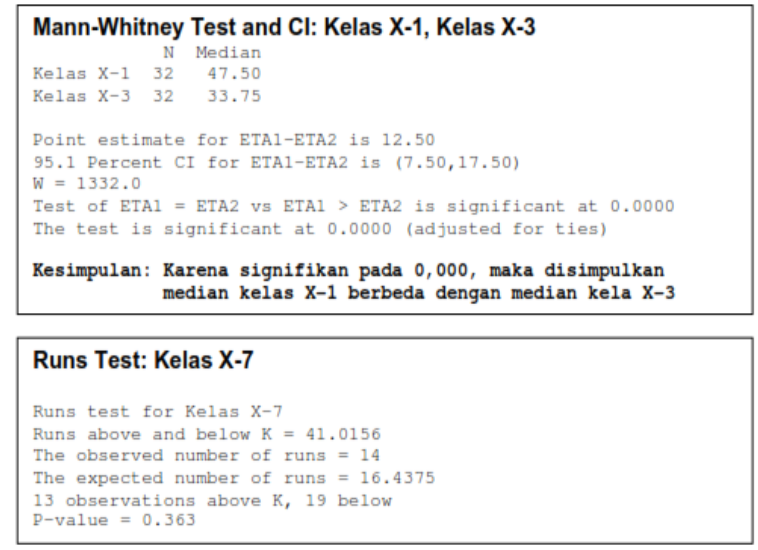

Gambar 5. Hasil Analisis Non Parametrik

Hasil analisis pekerjaan guru matematika SMA di Kabupaten Pesisir Selatan seperti yang telah diuraikan di atas, menunjukkan bahwa terja di peningkatan kemampuan dan keterampilan guru dalam melakukan analisis data. Sebelum kegiatan pelatihan, sebagian besar guru belum memahami secara baik tentang konsep-konsep dasar statistika, termasuk mamanfaatkan soft ware statistika untuk analisis data. Untuk meyakini perubahan tersebut, peserta diberi posttest pada akhir kegiatan pelatihan. Hasil post-test dibandikan dengan hasil pre-test. Hasil analisis pre-test dan pos-test adalah sebagai berikut. Gam 
bar 6 dan Gambar 7 menyajikan secara deskriptif hasil pre-test dan pos-test.

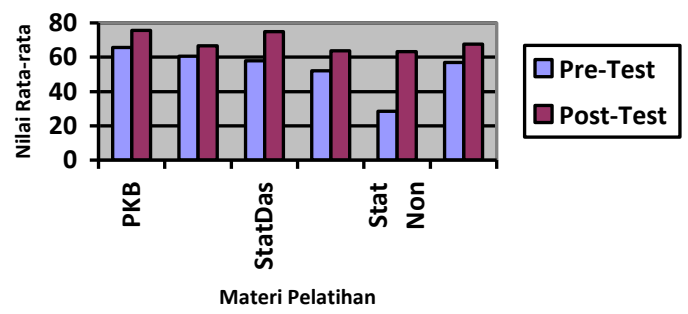

Gambar 6. Deskripsi Perbandingan Hasil Pre-Test dan Post-Test

Gambar 6 menunjukkan bahwa hasil posttest selalu lebih tinggi dari hasil pre-test untuk setiap topik pelatihan yang diberikan. Hal ini juga terlihat dari diagram kotak garis pada Gambar 7 yang terlihat bahwa diagram kotak garis nilai post-test jauh lebih tinggi dari diagram kotak garis nilai pre-test.

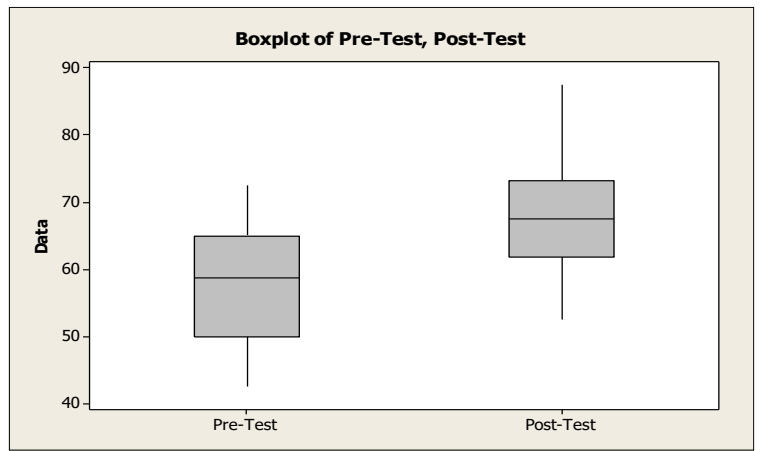

Gambar 7. Diagram Kotak-Garis Hasil Pre-Test dan Post-Test Peserta Pelatihan

Pembuktian secara statistik bahwa telah terjadi peningkatan pemahaman topik-topik pela tihan dilakukan analisis statistika parametrik dengan uji data berpasangan yang hasilnya ter lihat pada Tabel 2 .

Tabel 2 memperlihatkan hasil uji hipotesis untuk membandingkan perbedaan antara rata-rata nilai post-test dan rata-rata nilai pre-test peserta pelatihan. Secara keseluruan (general) tampak bahwa rata-rata nilai post-test lebih tinggi dari rata-rata nilai pre-test. Ini menunjukkan bahwa terjadi peningkatan rata-rata pengetahuan tentang analisis data guru-guru matematika SMA Kabu paten Pesisir Selatan setelah mengikuti pelatihan. Hasil uji hipotesis juga menunjukkan bahwa nilai p-value $=0.000$ kurang dari taraf siginifikasi 0,05 , ini menunjukkan bahwa rata-rata penge tahuan tentang analisis data guru-guru matema tika SMA Kabupaten Pesisir Selatan setelah mengikuti pelatihan lebih baik dari sebelum mengikuti pelatihan.

Tabel 2. Uji Hipotesis Perbandingan Rata-rata Nilai Pre-Test dan Nilai Post-Test Menurut Topik Pelatihan.

\begin{tabular}{|l|c|c|c|c|}
\hline \multirow{2}{*}{ Materi } & \multicolumn{2}{|c|}{ Rataan } & \multirow{2}{*}{ T- } & \multirow{2}{*}{ P-Value } \\
\cline { 2 - 3 } & $\begin{array}{c}\text { Pre- } \\
\text { Test }\end{array}$ & $\begin{array}{c}\text { Post- } \\
\text { Test }\end{array}$ & Value & \\
\hline PKB & 65.56 & 75.56 & 2.07 & 0.024 \\
\hline PTK dan KI & 60.48 & 66.59 & 2.89 & 0.004 \\
\hline Dasar Statistika & 57.78 & 75.00 & 4.27 & 0.000 \\
\hline Stat. Parametrik & 52.00 & 63.67 & 3.37 & 0.001 \\
\hline Stat. Non Parametrik & 28.33 & 63.33 & 5.46 & 0.000 \\
\hline General & $\mathbf{5 6 . 8 3}$ & $\mathbf{6 7 . 5 8}$ & $\mathbf{6 . 4 9}$ & $\mathbf{0 . 0 0 0}$ \\
\hline
\end{tabular}

Jika dilihat pada setiap topik materi yang dilatihkan, maka terlihat bahwa terjadi pening katan yang signifikan kemampuan pemahaman peserta pelatihan terhadap materi-materi yang dilatihkan setelah pelatihan berakhir, dengan demikian pelatihan yang diselenggarakan cukup bermakna dalam meningkatkan kemampuan peserta dalam menguasai konsep analisis data dalam penulisan karya ilmiah.

\section{KESIMPULAN}

Pemberian pelatihan berupa pendalaman materi dan pemanfaatan software statistika da lam menganalisis data penelitian dapat mening katkan pemahaman guru-guru matematika SMA Kabupaten Pesisir Selatan terhadap konsepkonsep dasar statistika, tentang: jenis dan kiat menulis karya ilmiah, data dan statistik, analisis statistika deskriptif, dan analisis statistika infe rensial. Selain itu, pelatihan dapat meningkatkan keterampilan para guru dalam melakukan anali sis data menggunakan software statistika serta menginterpretasikan hasil analisis.

\section{DAFTAR PUSTAKA}

Batanero, C. 2000. Controversies around the Role of Statistical Tests in Experimental Research. Mathematical Thinking and Learning, 2 (1-2): 75-98.

Bluman, A. G. 2012. Elementary statistics: A step by step approach. 8th ed. New York: McGraw Hill.

Castro Sotos, A. E., Vanhoof, S., Noortgate, W. V. den, \& Onghena, P. 2007. Students' misconceptions of statistical inference: A review of the empirical evidence from research on statistics education. Educational Research Review, 2, 98 - 113. 
Depdiknas. 2005. Undang-undang Nomor 14 Tahun 2005 tentang guru dan dosen. Jakarta: Depdiknas. 2009. Peraturan Menteri Negara Pendayagunaan Aparatur Negara dan Reformasi Birokrasi Nomor 16 Tahun 2009 tentang Jabatan Fungsional Guru dan Angka Kreditnya. Jakarta: Depdiknas

Garfield, J., \& Ahlgren, A. 1988. Difficulties in learning basic concepts in probability and statistics: implications for research. Journal for Research in Mathematics Education, 19, 44-63.

Glenberg, Arthur M. \& Matthew E. A. 2008. Learning from data: an introduction to statistical reasoning. New York: Lawrence Erlbaum Associate.

Haller, H., \& Krauss, S. 2002. Misinterpretations of significance: A problem students share with their teachers? Methods of Psychological Research, 7(1) : 1 - 20.

Hasan, Iqbal. 2004. Analisis Data Penelitian dengan Statistik. Jakarta: Bumi Aksara.
Holt, Melinda, M. \& Scariano, Stephen. M. 2009. Mean, Median and Mode from a Decision Perspective . Journal of Statistics Education 17(3): 1-16.

Mahsunah, dkk. 2013. Kebijakan Pengembangan Profesi Guru. Jakarta: Kementerian Pendidikan dan Kebudayaan.

Mendez, H. 1991. Understanding the central limit theorem. (Doctoral dissertation, University of California, Santa Barbara, 1991). Dissertation Abstracts International, 53, 2722.

Thompson, P., Liu, Y., \& Saldanha, L. 2007. Intricacies of Statistical Inference and Teachers' Understandings of Them. In M. C. Lovett \& P. Shah (Eds.), Thinking with data (1st ed., hal. 207 - 231). Mahwah, NJ: Psychology Press.

Walpole, Ronald. E. 1993. Introduction to Statistics, $3^{\text {rd }}$ edition. New York: John Willey \& Son 